\title{
A Comparative Study on SMall IndUStries Conducted by WOMEN in SOCIETIES Productive faMilies at THREE GOVERnORATES.
}

\author{
$B y$ \\ Howaida Mostafa Zaghlol Soheir Fawzy Mohamed
}

Faculty of Agriculture, Cairo University Faculty of Agriculture, Cairo University

Hanan Ahmed Reda Elgamal

Postgraduate student.

Research Gournal Specific Fducation

Faculty of Specific Education

gMansoura University

ISSUE NO. 47, JULY. 2017

مجلة بحوث التربية النوعية - جامعة المنصورة

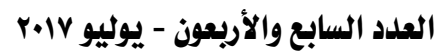




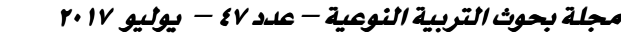

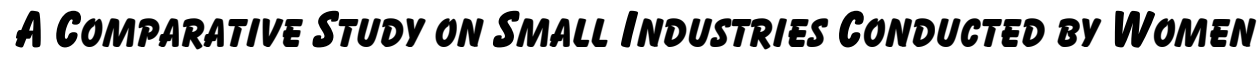 in SOCIETIES PrOductive families at Three Governorates.}

\section{Howaida Mostafa Zaghlol ${ }^{*} \quad$ Soheir Fawzy Mohamed ${ }^{* *}$ Hanan Ahmed Reda Elgamal}

\section{Abstract}

In recent years, the importance of handicrafts has been surged due to their cultural and financial values. The small scale industries, including handicrafts can play a major role in the development of the economy of both developed and the developing countries. Egyptian women work to share the burdens of everyday life because of their husband's death, illness or divorce. Therefore, the current study focused on the study of some small industries carried out by women in Societies Productive Families to meet the daily needs of their families.

The study was conducted in three Egyptian governorates (Cairo, Giza, and Fayoum) because they included Societies Productive Families (SPF), concerned with small industries which include handicrafts (leather bags, ceramic flowers, crochet, embroidery, itamin products and palm leaves products). The sample included 187 women who were chosen from 7 Societies Productive Families in three Egyptian Governorates.

The obtained results showed that about three quarter of women sample aged less than 40 years, $60.4 \%$ of them were married, more than half of sample (54\%) finished intermediate institute, less half of them (42.4 $\%)$ were housewife. The majority of the family types ( $85 \%)$ were simple, about half of sample had 4 to 5 persons $(51.9 \%)$. The highest percentage of socio-economic levels was above medium and medium $(60.4 \%)$ in the three governorates. The highest percentage of small industries existed in Cairo, Giza and Fayoum represented crochet, being $36.3 \%$, 53.6 \% and 43.1\% of the sample, respectively. The main problems facing families concerning

\footnotetext{
${ }^{*}$ Faculty of Agriculture, Cairo University

${ }_{* \star *}^{* *}$ Faculty of Agriculture, Cairo University

${ }^{* * *}$ Postgraduate student.
} 
small industries included the low return from the industries $(87.7 \%)$, the shortage of good raw materials at reasonable prices $(64.2 \%)$ and the rise in prices of raw materials (62.6\%). More than half of the households (57.2\%) were affected by the fact that the associations receive a high percentage of profits (15-20\%). Statistical analysis showed that the age of women was positively correlated with the husband's age, while negatively correlated with both women's education and socio-economic level. There were highly significant correlations between the education of women and each of the socio-economic level and the husband's education. Highly significant correlations between women's education and each of socio-economic level and husband's education were found. Women's education was negatively correlated with family size. A Highly significant correlation was observed between the occupation of women and the occupation of husbands. Husband's education was positively correlated with husband's occupation and socioeconomic level, while negatively correlated with family size.

\section{INTRODUCTION}

Egyptian population estimated to be about 92.8 million and growing at the rate of $2.1 \%$ annually. Unemployment rate accounted to $12.4 \%$ of the total population in Egypt. Women represent $45.3 \%$ of the total population in Egypt (CAPMS, 2017).

The small enterprises are the backbone of any economy. Nowadays when governmental or international institutions put forward a plan or policy, they show great concern about the role of the small enterprises in the economy as they know that these businesses are crucial to economic growth and development. Yet despite the importance of such enterprises for Egypt, obstacles often stand in the way of their development, such as financial and political issues, lack of technology adoption and unskilled workers. Egypt's current social and political transformation poses historic challenges and opportunities for its economic development and growth. The lack of employment opportunities, particularly for youth under the age of thirty five, there is an ever more urgent need to create jobs for young Egyptians. Developing countries usually view Micro, Small and Medium Enterprises 
(MSME) as a dynamic force for sustained economic growth and job creation. These enterprises not only create sustainable opportunities by expanding private-led employment, they also contribute to economic growth by bringing innovative products and services to the market, thereby increasing effectiveness and efficiency in the economy(Creative Associates International, 2014).

In Egypt, the small-scale industries have played a very important role in the socio economic development of the country during the past five decades; it has significantly contributed to the overall growth in terms of the gross domestic products. Therefore the performance of the small scale sector has a direct impact on the growth of the overall economy (Razia and Nida, 2014).

Small Scale Enterprises (SMEs) are crucial and important for poor societies as it contributes in improving people's livelihoods in the local community, by providing job opportunities, improving community services and increasing productivity of existing projects and eventually improving the national economy(Fanous, 2014).

During the recent years, the importance of handicrafts has been surged due to their cultural and financial values. The small scale industries, including handicrafts can play a major role in the development of the economy of both developed and the developing countries equally. About 90$95 \%$ of the total industrial products of the world are produced in small workshops run by less than 100 people. For instance, Japan, which is at the peak of the economic development, has considered $84 \%$ of its industries as small and medium scale industries. In countries such as India and China, handicrafts are as high as the mechanized products in quality and volume, and are a major source of their foreign earnings. These countries are focusing on the development of handicraft industry, in order to strengthen the economy. The handicraft sector is highly creative sector and produces large variety of crafts products. This industry is localized segment of the domestic and international market (Native American apparel, 2011). 
Small projects are the most important pillars of economic development, and one of the main ways to solve the problem of unemployment in the developing countries, as a problem of unemployment one of the main problems, and many felt that the focus on small projects is a model solution to get out of the economic crisis, so the study primarily focused on the most important study small industries (Hashem, 2008).

Small scale industries significantly contribute to social and economic development objectives such as labour absorption, income distribution, rural development poverty eradication, regional balance and promotion of entrepreneurship. In fact, they play an important role in process of country's industrial development. Particularly in the developing countries, small labour intensive industries have been favoured basically to create employment opportunities in an economy with abundant unskilled labour, even though such industries may not always support on grounds of economics efficiency. In addition, a low capital requirement given an appropriate market environment is beloved to stimulate growth of numerous indigenous, industries with wide regional dispersal. This helps to promote balanced growth ensure more equitable income distributional as well as diversification of the industrial structure, which often leads to increased utilization of national resource (Birajdar, 2011).

Women entrepreneur may be defined as women or group of women who initiate, organize and run a business entrepreneur (Kalavathi et al., 2008). According to a government of India definition, women entrepreneur based on women participation inequity and employment of a business enterprise.

In India, Ramasamy (2009) noted that women entrepreneurship can be considered as "necessity entrepreneurship" rather than "opportunity entrepreneurship". women usually have smaller networks and less geographical mobility than, more so in the case of young, married women who need to take care of their families. These women can use their skills and available local resources to start their own enterprise. However, the location of the enterprise and the strength of relationship with contact are 
very important as it determines the entrepreneur's ability to acquire and employ the resources available in her community.

The current study was conducted to study the small industries and socio-economic status of Societies Productive Families.

\section{Subjects and Methods}

\section{The Places of the Study:}

The current study was conducted in three Egyptian Governorates, namely Cairo, Giza, and Fayoum. These governorates were chosen as they included Societies Productive Families (SPF), which care for small industries which handicrafts (leather bags, ceramic flowers, crochet, embroidery, itamin and palm leaves products).

\section{Technique of Collecting Data:}

The data were collected through personal interview with women in their work place to fill the questionnaire sheet.

The sample included 187 women from Societies Productive Families were chosen as follows:

1. The sample chosen from Cairo Governorate included 80 surveyed subjects from three societies (27 women from "Hamcet Khair Society" at Helwan district, 26 women from "Downtown Cairo Society" at El-Darb El-Ahmer district and 27 women from "Society Productive Families" at El-Abassia district).

2. The sample chosen from Giza Governorate included 56 surveyed subjects, from two societies (29 women from "Local Community Development Society" at Bulaq El-Dakrror district and 27women from "Product Families Gallery" at waraq El-Arab district).

3. The sample chosen from Fayoum Governorate included 51surveyed subjects, from two societies, (26women from "Society Product Families" at down town district and 25 women from "S.T. Mariam's Society" at Com-Oshim district). 


\section{The questionnaire sheet included the following:}

3.1. Data concerning the socioeconomic characteristics of the women (age, marital status, educational and occupational status).

3.2. Data concerning the socioeconomic characteristics of the women's husbands (age, educational and occupational status).

3.3. Data related to family members status (family type and family size).

3.4. Data related to economic status (monthly income, electric instruments and house holding).

3.5. Data concerning the number and educational status of the sons and daughters.

3.7. Data concerning women's contributions in small industries including:

3.7.1. Distribution of women in different industries included handicrafts (Leather bags, ceramic flowers, crochet, embroidery, itamin and palm Leave products).

3.7.2. The used tools, materials, their stores, shops, prices, availability.

3.7.3. The budget and marketing.

3.7.4. Model sources and how the women learnt this industry.

3.8. Problems facing industry including the following:

3.8.1. The shortage of good raw materials at reasonable.

3.8.2. Societies receive a high percentage of profits (15-20\%).

3.8.3. The low return from the industries.

3.8.4. The difficulty of dealing with traders.

3.8.5. The rise in prices of raw materials.

3.8.6. Insufficiency of storage places.

3.8.7. Lake of promotion's exhibitions.

3.8.8. The shortage of available raw materials. 


\section{The evaluation of different variables}

\section{The socio-economic levels:}

The socioeconomic levels of the household were calculated according to the equation of El-Shakhs (2006) as follows:

Predicted socioeconomic levels $=0.073+0.264(\mathrm{C} 1)+0.284(\mathrm{C} 2)+$ $0.102(\mathrm{C} 3)+0.160(\mathrm{C} 4)+0.125(\mathrm{C} 5)$. Where:

C1: Average income of the household per month in Egyptian pound (L.E).

C2: Score of the woman's husband occupation.

C3: Score of the woman's husband education.

C4: Score of the woman's occupation.

C5: Score of the woman's education.

Average monthly income was assessed and families were divided into (4) scores as follows:

$$
\begin{array}{ll}
\text { Score }(1)<500 \text { L.E } & \text { Score }(2)>500-1000 \text { L.E } \\
\text { Score }(3)>1000-2000 \text { L.E } & \text { Score }(4)>2000 \text { L.E }
\end{array}
$$

The occupation of woman's husband, were divided into (6) scores as follows:

Score (1) Hawker, Score (2) Unprofessional labourer, Score (3) Professional labourer, Score (5) Private business, Score (6) Stores owner, and Score (4) Employee.

The occupation of woman, were divided into 6 scores as follows: Score (1) Hawker, Score (2) Housewife, Score (3) Professional labourer, Score (4) Nursery or teacher, Score (5) Employee and Score (6) Private business.

The education of woman and woman's husband were divided into (7) scores as follows: Score (1) Illiterate, Score (2) Primary school, Score (3) Preparatory school, Score (4) Secondary school, Score (5) Intermediate institute, Score (6) Graduate, and Score (7) Post graduate.

The socioeconomic levels were categorized as follows:

1) Low level (20 - 29 scores). 
- A Comparative Study on Small Industries Conducted by Women in Societies Productive Families

2) Below average level (30 - 39 scores).

3) Medium level (40 - 48 scores).

4) Above average level (49 - 58 scores).

5) High level more than (59 - 70 scores).

\section{Statistical analysis of data:}

The obtained data were statistically analysed according to Freund and Simon (2001) using the statistical package for social sciences (SPSS, 2011).

The analysis included the following items:

1. Frequencies and percentage distributions for the studied variables.

2. For the comparison between the different groups, Chi-square test $\left(\mathrm{x}^{2}\right)$ value was used to assess the relationship among some variables in the three governorates. The significant level was fixed at 0.01 and 0.05 with a given degree of freedom.

3. Correlation coefficients (r) between some variables were carried out to find the correlation between the concerned variables.

\section{RESULTS AND DISCUSSION}

Table (1) illustrated women's distribution according to their socioeconomic characteristics in the three governorates. Data showed that $70.1 \%$ of the women were less than 40 years, while $29.9 \%$ of them aged 40 years and more. Chi square proved no significant relationship between women`s age and the settlement.

Close to two thirds of them $(60.4 \%)$ of them were married, while the rest were single, divorced and widow, respectively. Chi square showed no significant relationship between marital status of women and the place.

With respect to educational status of women, data in table (1) showed that more than half of sample finished intermediate institutes, reasonable percentages of them ( one fourth) were graduates, and $2.1 \%$ had post graduate degrees. Meanwhile, only $4.3 \%, 1.6 \%$ and $3.2 \%$ got primary, preparatory and secondary school education, respectively. Only $2.7 \%$ were 
illiterate and $6.4 \%$ could read and write. Chi square assured no significant relationship between educational status of women and the governorate.

In the same table (1), data exhibited that less the half of the women $42.4 \%$ were housewife, while 18.2 and $13.3 \%$ were employees and nursery teachers, respectively. Furthermore, $12.8 \%$ worked in private business, but $7.5 \%$ and $5.8 \%$ were professional laborers and hawkers. Insignificant relationship between women' occupation and the governorate were found by Chi square.

Data concerning age, marital and occupation status of women were in harmony with those reported by other researchers (El-Gazzar, 2002, Mohamed, 2004, Mari, 5005, Ata, 2007, Mohamed, 2007, Ahmed and ElBendary, 2012 and Fanous, 2014). However, the previous studies were different in educational status. This might return to the type of the sample (urban and rural).

Concerning women's husbands' distribution according to their socioeconomic characteristics, data in table (2), revealed that less than half of them $(46.9 \%)$ had 40 years and more, while $36.3 \%$ aged $30-39$ years, and $16.8 \%$ were less than 30 years of age. The highest percentage of husbands who were less than 30 years was observed in Fayoum, followed by Giza and the least percent in Cairo. Those husbands who aged 30-39 years showed the highest percent in Fayoum, while their percepts in Cairo and Giza were close. In contrast, the lowest percentage of those aged 40 and more was found in Fayoum and in Cairo and Giza showed higher percepts that were close. Chi square showed high significant relationship between husbands' age and the governorate.

Regarding the educational status of women's husbands, data in table (2) showed that more than two third (68.2\%) of them finished intermediate institutes, $28.3 \%$ of the had secondary school education. Low percentages $(1.8 \%, 0.9 \%$ and $0.9 \%)$ were graduate, primary school and illiterate, respectively. The highest percentage of women' husbands who finished intermediate schools were noticed in Cairo governorate, whereas their percentages in the two other governorates (Fayom and Giza) were similar. 
None of husbands in Cairo and Giza and only one case were illiterate in Fayoum. In Cairo, only one husband had primary school education and two husbands were graduates. In Giza and Fayoum, none of the husbands fell in the categories (primary education or graduate). Chi square showed no significant relationship between women`s husbands' educational status in the three governorates.

With respect to women's husbands' occupation, data in table (2) showed that more than half of the sample were professional laborer and private business $(28.3 \%$ and $28.3 \%$, respectively). Employee represented $(19.5 \%)$, then came unprofessional laborer $(9.7 \%)$, hawker and store's owner $(7.1 \%$ and $7.1 \%)$. Chi square assured no significant relationship between women`s husbands' occupational status and the governorate.

In this respect, El-Gazzar (2002) in Giza Governorate, Mohamed (2004) in Giza Governorate, Ata (2007) in El-Dakahlia Governorate found differences in the age of the husband and education and occupational status of women's husbands due to the differences between samples and the district of the study.

Table (3) illustrated families' distribution according their type, size and monthly income in the three governorates. It could be noticed that majority of family types $(85 \%)$ were simple, while the extended type showed low percent (15\%), as the sample represented urban family type. Among the three governorates, the highest percent of simple families was noticed in Cairo, while in Fayoum the extended families showed the most existed type. Chi square showed significant relationship between family types and the governorate.

Similar results were obtained by several studies in rural areas of Egypt El-Gazzar (2002) in Giza Governorate, Mohamed (2004) in Giza Governorate, Ata (2007) in El-Dakahlia Governorate.

Concerning family size data in table (3) also showed that about half of the sample (51.9\%) had 4 to 5 persons, and for $32.1 \%$ family members exceeded 6persons, while $16 \%$ of them had 3 persons or less. Chi square showed no significant relationship between family size and the governorate. 
Similar findings were reported by Mari (2005) in Menoufia Governorate and Fanous (2014) in El-Sharkia Governorate. In contrast, the studies of El-Gazzar (2002) in Giza Governorate, Mohamed (2004) in Giza Governorate, Ata (2007) in El-Dakahlia Governorate, Mohamed (2007) in Fayoum Governorate, showed big families having more than 5 persons.

With regard to the monthly income, data in table (3) demonstrated that monthly income for more than three quarters of the sample (79.6\%) fluctuated between $\geq 500$ to 2000 Egyptian Pound. The income less than 500 Egyptian Pound was noticed for $17.6 \%$ of the families. Only a very small percentage (2.7\%) had income more than 2000 Egyptian Pound. Chi square showed no significant relationship between monthly incomes and the governorate.

These findings were different from those of Mohamed (2004) in Giza Governorate, Mari (2005) in Menoufia Governorate, Ata (2007) in ElDakahlia Governorate, Mohamed (2007) in Fayoum Governorate and Fanous (2014) in El-Sharkia Governorate due to the different occupation and education levels besides the time of assessment.

Concerning different levels of socio-economic in the three governorates, data in table (4) illustrated that the medium level showed the highest percentages in Cairo, Giza and Fayoum (30\%, $41.1 \%$ and $49 \%$, respectively). The low medium level percentage accounted $22.5 \%, 14.3 \%$ and $19.6 \%$ in the three governorates respectively. Low level recorded the lowest percentage in the three governorates $(9.1 \%)$. However, high or above medium levels in Cairo and Giza Governorate exceeded those in Fayoum. The statistical analysis of data showed that there were insignificant differences among the levels in the three governorates.

The obtained findings were in the same line with these of El-Arabi (2010) in Giza Governorate.

Concerning sons and daughter's distribution according to their number, data in table (5) showed that more than half of the sample had one son and the rest of families had two or three sons. No significant relationship between numbers of sons was found. 
The majority of the families having one and two daughters represented $47.3 \%$ and $40 \%$, respectively. Only $12.7 \%$ of the families had three daughters. The highest percent of women having one or three daughters was found in In Fayoum, followed by Giza and then Cairo. However, the families with two daughters were observed in Cairo, followed by Giza and then In Fayoum. Chi square showed significant relationship between numbers of daughters and the governorate.

Concerning sons and daughters' distributions according their education, data in table (6) revealed that $66.4 \%$ of sons and $63.1 \%$ of daughters had primary and preparatory education, respectively. While secondary educations were noticed for $13.6 \%$ and $14.3 \%$ for sons and daughters, respectively. Data in table (6) also showed that similar percentages ( $16.8 \%$ of sons, and $16.6 \%$ of daughters) had intermediate institute and graduate education. Insignificant relationships were found between the governorates with either the education of sons or daughters' education.

Data in table (7) demonstrated that more than half of the sample (53.6 \%) had crochet, but $23.2 \%$ and $17.9 \%$ made natural and artificial leather bags, while the least industry was embroidery (5.4\%). In Fayoum Governorate, data indicated that crochet had the highest percentage (43.1\% of small industries), followed by palm leaves products $(23.5 \%)$, and then came embroidery (19.6\%) and itamin (13.7\%).

In this respect, Mohamed (2007) in Fayoum Governorate reported close results for embroidery and sewing. However, Mohamed (2004) in Giza Governorate noticed the highest percentage of the industries was embroidery (96.0\%). Such difference might be ascribed to the place study.

Data in table (8) presented the problems facing the families concerning small industries. The main problems included the low return from the industries $(87.7 \%)$, the shortage of good raw materials at reasonable prices $(64.2 \%)$ and the rise in prices of raw materials $(62.6 \%)$. Meanwhile, $48.1 \%$ of the families suffered from the lack of promotional exhibitions. . More than half of the households (57.2\%) were affected by the 
fact that the associations receive a high percentage of profits (15-20\%). The difficulty of dealing with traders was the problem of quarter of the sample $(25.1 \%)$. The lack of raw materials recorded by $18.7 \%$ of the women. The lowest percentage of the families $(18.2 \%)$ mentioned the insufficiency of storage place.

In the studies of Mohamed (2004) in Giza Governorate, Maged (2007) in Fayoum Governorate and Hashem (2008) in Fayoum Governorate, the problems included unavailability of high quality raw materials at suitable prices, the low return from the industries, and the rise in prices of raw materials and distance to marketing place.

The statistical analysis of data among some variables is shown in table (9).The presented data proved that the age of women was highly positively correlated with the husband's age, while negatively correlated with both women's education and socio-economic level. There were highly significant correlations between the education of women and each of the socio-economic level and the husband's education. Highly significant correlations between women's education and each of socio-economic level and husband's education were found. Women's education was negatively correlated with family size. A Highly significant correlation was observed between the occupation of women and the occupation of husbands. Husband's education was positively correlated with husband's occupation and socioeconomic level, while negatively correlated with family size.

\section{References}

- Ahmed, L.A. and Bendary, S.A. (2012). The Role of Rural Women Leaders in Promotion of Girl to Set up Small Projects in Some Villages of Alexandria and Behaira Governorates. Alexandria Science Exchange Journal, 23, (1):1-11.

- Ata, E.M. (2007). Women's Role in Different Activities and Family Resources Management and its Relations to Development. M.Sc. Thesis, Home Economics, Faculty of Agriculture, Cairo University.

- Birajdar, S.M. (2011). A Study of The Small Scale Industries in Economic Development in Kolhapur District. Golden Research Thoughts, 1(v):1- 4. 
- CAPMS (2017). Central Agency for Public Mobilization and Statistics, Egypt in Figures 2017. http://www.capmas.gov.eg

- Creative Associates International (2014) Micro, Small and Medium Enterprises in Egypt. Special Focus on Entrepreneurship, Streamlining Business Procedures and Value Chain Analysis. http://www.creativeassociatesinternational.com

- El-Arabi, N.H.A. (2010). The Relationship between Nutritional Status and Lifestyle Factors among Adolescents in Giza Governorate. Ph.D. Thesis, Faculty of Agric. Cairo Univ. Egypt.

- El-Gazzar, A.A. (2002). Studies on the Role of Rural Women in Motherhood and Childhood Development in Giza Governorate. Ph.D. Thesis, Home Economics, Faculty of Agriculture, Cairo University, 272 pp.

- El-Shakhs, A.EL.(2006). The measurement of socio-economic level of the family. Education College. Ain Shams University. Egyptian-Anglo Library, $3 \square$ $\square$ ed, 20 p.

- Fanous, M.S.(2014). Some Variables Related to the Degree of Benefit of Small Enterprises 'Owners Funded by the Social Fund for Development' in Some Villages of Sharkia Governorates. Ph.D. Thesis, Rural Sociology, Faculty of Agriculture, Cairo University.

- Hashem, R.A. (2008). An economic study for some small agricultural enterprises in the governorate of Fayoum. Ph.D. Faculty of Agric., Fayoum Univ. Egypt.

- Kalavathi, M.S. and Leela, V. (2008). " Micro Credit in Villupuram District", Kisan World, Vol.35, No.8, pp.8-9.

- Maged, Z.H.(2007). The degree of the graduates benefits from training program presented by rural development centres to establish a small production project in a Village Fayoum Governorate. J. Agric. Sci. Mansoura Univ., 32 (8): 68676882.

- Mari, H.E.(2005). Suggestions and Solutions to Face the Problems of the Rural House Wife Which are Connected to Small Industries. M.Sc. Thesis, Faculty of Home Economics, Menoufiya University, 218 pp.

- Mohamed, E.A. (2007). A Study Impact of the Development Projects Financed by the Local Development Fund Which Devoted for the Rural Women in Fayoum Governorate. Ph.D. Thesis, Rural Sociology, Faculty of Agriculture, Cairo University. 
- Mohamed, N.A.E. (2004). Effect of Small Industries on Woman's Role in Decision Making and Rural Family Development. M.Sc. Faculty of Agric. Cairo Univ. Egypt.

- Native American apparel. (2011). Indian Handicrafts Industry- An overview, About Indian Handicrafts Industry.http://www.india-crafts.com.

- Ramasamy, T.(2009). "Strategic Entrepreneurial Dimensions of Self-Employed Women A Micro Study”. Southern Economist, Vol.48, No.14, 39-41.

- Razia, B. and Nida, F. (2014). Role of small scale industry and women empowerment: A case study in carpet industry of Bhadohi District, U.P. International Journal of Management, IT and Engineering, 4(3):152-164.

- SPSS. (2011). Statistical package for social sciences for windows, Rel 11.0.1.2001. Chicago: SPSS inc http://www.spss.com. 
Table 1. Women's distribution according to their socio-economic characteristics in the three Governorates.

\begin{tabular}{|c|c|c|c|c|c|c|c|c|}
\hline & \multicolumn{6}{|c|}{ Governorates } & \multirow{2}{*}{\multicolumn{2}{|c|}{ Total }} \\
\hline & \multicolumn{2}{|c|}{ Cairo } & \multicolumn{2}{|c|}{ Giza } & \multicolumn{2}{|c|}{ Fayoum } & & \\
\hline & No. & $\%$ & No. & $\%$ & No. & $\%$ & No. & $\%$ \\
\hline Age (Year) & & & & & & & & \\
\hline$<30$ & 31 & 38.8 & 16 & 28.6 & 25 & 49.0 & 72 & 38.5 \\
\hline $30-39$ & 20 & 25.0 & 22 & 39.3 & 17 & 33.3 & 59 & 31.6 \\
\hline 40 and more & 29 & 36.2 & 18 & 32.1 & 9 & 17.6 & 56 & 29.9 \\
\hline Marital status & & & & & & & & \\
\hline Married & 42 & 52.5 & 39 & 69.6 & 32 & 62.7 & 113 & 60.4 \\
\hline Single & 19 & 23.8 & 7 & 12.5 & 7 & 13.7 & 33 & 17.6 \\
\hline Widow & 7 & 8.8 & 5 & 8.9 & 5 & 9.8 & 17 & 9.1 \\
\hline Divorced & 12 & 15.0 & 5 & 8.9 & 7 & 13.7 & 24 & 12.8 \\
\hline Educational status (3) & & & & & & & & \\
\hline Illiterate & 1 & 1.2 & 1 & 1.8 & 3 & 5.9 & 5 & 2.7 \\
\hline Read and write & 3 & 2.5 & 3 & 5.4 & 6 & 11.8 & 12 & 6.4 \\
\hline Primary school & 2 & 0.0 & 3 & 5.4 & 3 & 5.9 & 8 & 4.3 \\
\hline Preparatory school & 0 & 5.0 & 1 & 1.8 & 2 & 3.9 & 3 & 1.6 \\
\hline Secondary school & 4 & 5.0 & 1 & 1.8 & 1 & 2.0 & 6 & 3.2 \\
\hline Intermediate institute & 42 & 52.6 & 30 & 53.6 & 29 & 56.9 & 101 & 54.0 \\
\hline Graduate & 27 & 33.8 & 16 & 28.6 & 5 & 9.8 & 48 & 25.7 \\
\hline Post graduate & 1 & 1.2 & 1 & 1.8 & 2 & 3.9 & 4 & 2.1 \\
\hline Occupational status (4) & & & & & & & & \\
\hline Hawker & 7 & 8.8 & 2 & 3.6 & 2 & 3.9 & 11 & 5.8 \\
\hline Housewife & 25 & 31.2 & 26 & 46.4 & 28 & 54.9 & 79 & 42.4 \\
\hline Professional laborer Nursery & 7 & 8.8 & 4 & 7.1 & 3 & 5.9 & 14 & 7.5 \\
\hline teacher & 12 & 15.0 & 10 & 17.8 & 3 & 5.9 & 25 & 13.3 \\
\hline Employee & 18 & 22.5 & 11 & 9.6 & 5 & 9.8 & 34 & 18.2 \\
\hline Private business & 11 & 13.8 & 3 & 5.4 & 10 & 19.6 & 24 & 12.8 \\
\hline Total & 80 & 100.0 & 56 & 100.0 & 51 & 100.0 & 187 & 100.0 \\
\hline
\end{tabular}
(1) $\square^{2}=8.83$
(3) $\square^{2}=19.86$
(2) $\square^{2}=5.66$
(4) $\square^{2}=17.24$ 
Table 2. Women's husband distribution according to their socioeconomic characteristics in the three Governorates.

\begin{tabular}{|c|c|c|c|c|c|c|c|c|}
\hline & \multicolumn{6}{|c|}{ Governorates } & \multirow{2}{*}{\multicolumn{2}{|c|}{ Total }} \\
\hline & \multicolumn{2}{|c|}{ Cairo } & \multicolumn{2}{|c|}{ Giza } & \multicolumn{2}{|c|}{ Fayoum } & & \\
\hline & No. & $\%$ & No. & $\%$ & No. & $\%$ & No. & $\%$ \\
\hline Age (Year) & & & & & & & & \\
\hline$<30$ & 4 & 9.5 & 4 & 10.3 & 11 & 34.4 & 19 & 16.8 \\
\hline |30-39 & 14 & 33.3 & 12 & 30.8 & 15 & 46.9 & 41 & 36.3 \\
\hline 40 and more & 24 & 57.1 & 23 & 59.0 & 6 & 18.8 & 53 & 46.9 \\
\hline Educational status (2) & & & & & & & & \\
\hline Illiterate & 0 & 0.0 & 0 & 0.0 & 1 & 3.1 & 1 & 0.9 \\
\hline Primary school & 1 & 2.4 & 0 & 0.0 & 0 & 0.0 & 1 & 0.9 \\
\hline Secondary school & 9 & 21.4 & 13 & 33.3 & 10 & 31.2 & 32 & 28.3 \\
\hline Intermediate institute & 30 & 71.5 & 26 & 66.7 & 21 & 65.7 & 77 & 68.2 \\
\hline Graduate & 2 & 4.8 & 0 & 0.0 & 0 & 0.0 & 2 & 1.8 \\
\hline Occupational status (3) & & & & & & & & \\
\hline Hawker & 5 & 11.9 & 2 & 5.1 & 1 & 3.1 & 8 & 7.1 \\
\hline Unprofessional laborer & 6 & 14.2 & 2 & 5.1 & 3 & 9.3 & 11 & 9.7 \\
\hline Professional laborer & 10 & 23.8 & 13 & 33.3 & 9 & 28.1 & 32 & 28.3 \\
\hline Employee & 5 & 11.9 & 8 & 20.5 & 9 & 28.1 & 22 & 19.5 \\
\hline Private business & 12 & 28.6 & 11 & 28.2 & 9 & 28.1 & 32 & 28.3 \\
\hline Stores owner & 4 & 9.5 & 3 & 7.7 & 1 & 3.1 & 8 & 7.1 \\
\hline Total & 42 & 100.0 & 39 & 100.0 & 32 & 100.0 & 113 & 100.0 \\
\hline
\end{tabular}
(1) $\square^{2}=17.16 * *$
(2) $\square^{2}=8.85$
(3) $\square^{2}=8.26$ 
Table 3. Families' distribution according their type, size and monthly income in the three Governorates.

\begin{tabular}{|c|c|c|c|c|c|c|c|c|}
\hline & \multicolumn{6}{|c|}{ Governorates } & \multirow{2}{*}{\multicolumn{2}{|c|}{ Total }} \\
\hline & \multicolumn{2}{|c|}{ Cairo } & \multicolumn{2}{|c|}{ Giza } & \multicolumn{2}{|c|}{ Fayoum } & & \\
\hline & No. & $\%$ & No. & $\%$ & No. & $\%$ & No. & $\%$ \\
\hline Family type & & & & & & & & \\
\hline Simple & 73 & 91.2 & 49 & 87.5 & 37 & 72.5 & 159 & 85.0 \\
\hline Extended & 7 & 8.8 & 7 & 12.5 & 14 & 27.5 & 28 & 15.0 \\
\hline Total & 80 & 100.0 & 56 & 100.0 & 51 & 100.0 & 187 & 100.0 \\
\hline Family size & & & & & & & & \\
\hline 3 persons and less & 10 & 12.5 & 9 & 16.1 & 11 & 21.6 & 30 & 16.0 \\
\hline 4-5 persons & 43 & 53.8 & 31 & 55.4 & 23 & 45.1 & 97 & 51.9 \\
\hline 6 persons and more & 27 & 33.8 & 16 & 28.6 & 17 & 33.3 & 60 & 32.1 \\
\hline Total & 80 & 100.0 & 56 & 100.0 & 51 & 100.0 & 187 & 100.0 \\
\hline Monthly income (Egyptian pound) (3) & & & & & & & & \\
\hline$<500$ & 10 & 12.5 & 12 & 21.4 & 11 & 21.6 & 33 & 17.6 \\
\hline$>500-1000$ & 46 & 57.5 & 29 & 51.8 & 27 & 52.9 & 102 & 54.5 \\
\hline$>1000-2000$ & 23 & 28.8 & 13 & 23.2 & 11 & 21.6 & 47 & 25.1 \\
\hline$>2000$ & 1 & 1.2 & 2 & 3.6 & 2 & 3.9 & 5 & 2.7 \\
\hline Total & 80 & 100.0 & 56 & 100.0 & 51 & 100.0 & 187 & 100.0 \\
\hline
\end{tabular}
(1) $\square^{2}=8.94^{*}$
(2) $\square^{2}=2.54$
(3) $\square^{2}=4.15$ 
Table 4. Different levels of socioeconomic in the three Governorates.

\begin{tabular}{||c|c|c|c|c|c|c|c|c||}
\hline \multirow{3}{*}{ Socio-economic level } & \multicolumn{6}{|c||}{ Governorates } & \multicolumn{2}{|c|}{ Total } \\
\cline { 2 - 11 } & \multicolumn{2}{|c|}{ Cairo } & \multicolumn{2}{c|}{ Giza } & \multicolumn{2}{c|}{ Fayoum } & \multicolumn{2}{||}{} \\
\cline { 2 - 11 } & No. & $\%$ & No. & $\%$ & No. & $\%$ & No. & $\%$ \\
\hline \hline High & 9 & 11.2 & 6 & 10.7 & 6 & 11.8 & 21 & 11.2 \\
\hline Above medium & 22 & 27.5 & 14 & 25.0 & 5 & 9.8 & 41 & 21.9 \\
\hline Medium & 24 & 30.0 & 23 & 41.1 & 25 & 49.0 & 72 & 38.5 \\
\hline Below medium & 18 & 22.5 & 8 & 14.3 & 10 & 19.6 & 36 & 19.3 \\
\hline Low & 7 & 8.8 & 5 & 8.9 & 5 & 9.8 & 17 & 9.1 \\
\hline Total & 80 & 100.0 & 56 & 100.0 & 51 & 100.0 & 187 & 100.0 \\
\hline
\end{tabular}

Table 5. Sons and daughters distribution according to their number in three Governorates.

\begin{tabular}{|c|c|c|c|c|c|c|c|c|}
\hline & \multicolumn{6}{|c|}{ Governorates } & \multirow{2}{*}{\multicolumn{2}{|c|}{ Total }} \\
\hline & \multicolumn{2}{|c|}{ Cairo } & \multicolumn{2}{|c|}{ Giza } & \multicolumn{2}{|c|}{ Fayoum } & & \\
\hline & No. & $\%$ & No. & $\%$ & No. & $\%$ & No. & $\%$ \\
\hline Number of sons & & & & & & & & \\
\hline 1 son & 26 & 52.0 & 28 & 65.1 & 22 & 55.0 & 76 & 57.1 \\
\hline 2 sons & 21 & 42.0 & 12 & 27.9 & 15 & 37.5 & 48 & 36.1 \\
\hline 3 sons & 3 & 6.0 & 3 & 7.0 & 3 & 7.5 & 9 & 6.8 \\
\hline Number of daughters & & & & & & & & \\
\hline 1 daughter & 17 & 35.4 & 15 & 39.5 & 20 & 83.3 & 52 & 47.3 \\
\hline 2 daughters & 26 & 54.2 & 15 & 39.5 & 3 & 12.5 & 44 & 40.0 \\
\hline 3 daughters & 5 & 10.4 & 8 & 21.1 & 1 & 4.2 & 14 & 12.7 \\
\hline Total & 48 & 100.0 & 38 & 100.0 & 24 & 100.0 & 110 & $\begin{array}{c}100 . \\
0\end{array}$ \\
\hline
\end{tabular}

(1) $\square^{2}=2.124$

(2) $\square^{2}=19.119^{* *}$ 
Table 6. Sons and daughters distribution according to their educational status in three Governorates.

\begin{tabular}{|c|c|c|c|c|c|c|c|c|}
\hline \multirow[t]{3}{*}{ Educational status } & \multicolumn{6}{|c|}{ Governorates } & \multirow{2}{*}{\multicolumn{2}{|c|}{ Total }} \\
\hline & \multicolumn{2}{|c|}{ Cairo } & \multicolumn{2}{|c|}{ Giza } & \multicolumn{2}{|c|}{ Fayoum } & & \\
\hline & No. & $\%$ & No. & $\%$ & No. & $\%$ & No. & $\%$ \\
\hline Educational status of son & & & & & & & & \\
\hline Primary school & 15 & 25.4 & 19 & 36.5 & 19 & 44.2 & 53 & 34.4 \\
\hline Preparatory school & 20 & 33.9 & 17 & 32.7 & 13 & 30.2 & 50 & 32.5 \\
\hline Secondary school & 9 & 15.3 & 7 & 13.5 & 5 & 11.6 & 21 & 13.6 \\
\hline Intermediate institute & 5 & 1.7 & 3 & 5.8 & 3 & 7.0 & 11 & 4.5 \\
\hline Graduate & 10 & 16.9 & 6 & 11.5 & 3 & 7.0 & 19 & 12.3 \\
\hline Educational status of daughter (2) & & & & & & & & \\
\hline Primary school & 21 & 36.2 & 18 & 34.0 & 10 & 45.5 & 49 & 36.8 \\
\hline Preparatory school & 13 & 22.4 & 15 & 28.3 & 7 & 31.8 & 35 & 26.3 \\
\hline Secondary school & 9 & 15.5 & 8 & 15.1 & 2 & 9.1 & 19 & 14.3 \\
\hline Intermediate institute & 10 & 6.9 & 6 & 9.4 & 3 & 9.1 & 19 & 8.3 \\
\hline Graduate & 5 & 8.6 & 6 & 11.3 & 0 & 0.0 & 11 & 8.3 \\
\hline
\end{tabular}

(1) $\square^{2}=13.264$

(2) $\square^{2}=7.788$

Table 7. Families' distribution according to the excited small industries in the three governorates.

\begin{tabular}{|c|c|c|c|c|c|c|c|c|}
\hline \multirow{3}{*}{ Small Industries } & \multicolumn{6}{|c|}{ Governorates } & \multirow{2}{*}{\multicolumn{2}{|c|}{ Total }} \\
\hline & \multicolumn{2}{|c|}{ Cairo } & \multicolumn{2}{|c|}{ Giza } & \multicolumn{2}{|c|}{ Fayoum } & & \\
\hline & No. & $\%$ & No. & $\%$ & No. & $\%$ & No. & $\%$ \\
\hline Crochet & 29 & 36.2 & 30 & 53.6 & 22 & 43.1 & 81 & 43.3 \\
\hline Natural leather bags & 18 & 22.5 & 13 & 23.2 & 0 & 0.0 & 31 & 16.6 \\
\hline Artificial leather bags & 17 & 21.2 & 10 & 17.9 & 0 & 0.0 & 27 & 14.4 \\
\hline Ceramics flowers & 6 & 7.5 & 0 & 0.0 & 0 & 0.0 & 6 & 3.2 \\
\hline Embroidery & 10 & 12.5 & 3 & 5.4 & 10 & 19.6 & 23 & 12.3 \\
\hline Palm leaves products & 0 & 0.0 & 0 & 0.0 & 12 & 23.5 & 12 & 6.4 \\
\hline Itamin & 0 & 0.0 & 0 & 0.0 & 7 & 13.7 & 7 & 3.7 \\
\hline Total & 80 & 100.0 & 56 & 100.0 & 51 & 100.0 & 187 & 100.0 \\
\hline
\end{tabular}


Table 8. The problems facing the women at small industries in the three Governorates.

\begin{tabular}{|c|c|c|c|c|c|c|c|c|}
\hline \multirow{3}{*}{ Items } & \multicolumn{6}{|c|}{ Governorates } & \multirow{2}{*}{\multicolumn{2}{|c|}{ Total }} \\
\hline & \multicolumn{2}{|c|}{ Cairo } & \multicolumn{2}{|c|}{ Giza } & \multicolumn{2}{|c|}{ Fayoum } & & \\
\hline & No. & $\%$ & No. & $\%$ & No. & $\%$ & No. & $\%$ \\
\hline $\begin{array}{l}\text { The shortage of good raw materials at } \\
\text { reasonable prices }\end{array}$ & 53 & 66.2 & 39 & 69.6 & 28 & 54.9 & 120 & 64.2 \\
\hline $\begin{array}{l}\text { Societies receive a high percentage of } \\
\text { profits }(15-20 \%)\end{array}$ & 58 & 72.5 & 47 & 83.9 & 2 & 3.9 & 107 & 57.2 \\
\hline The low return from the industries & 73 & 91.2 & 49 & 87.5 & 42 & 82.4 & 164 & 87.7 \\
\hline The difficulty of dealing with traders & 27 & 33.8 & 18 & 32.1 & 2 & 3.9 & 47 & 25.1 \\
\hline The rise in prices of raw materials & 51 & 63.8 & 32 & 57.1 & 34 & 66.7 & 117 & 62.6 \\
\hline Insufficiency of storage places & 19 & 23.8 & 10 & 17.9 & 5 & 9.8 & 34 & 18.2 \\
\hline Lake of promotion's exhibition & 28 & 35.0 & 22 & 39.3 & 40 & 78.4 & 90 & 48.1 \\
\hline $\begin{array}{l}\text { The shortage of available raw } \\
\text { materials }\end{array}$ & 9 & 11.2 & 13 & 23.2 & 13 & 25.5 & 35 & 18.7 \\
\hline
\end{tabular}

Table 9. Correlation coefficients among some socioeconomic characteristics of the sample in the three governorates.

\begin{tabular}{||c||c|c|c|c|c|c|c||}
\hline & $\begin{array}{c}\text { Women's } \\
\text { age }\end{array}$ & $\begin{array}{c}\text { Women's } \\
\text { education }\end{array}$ & $\begin{array}{c}\text { Women's } \\
\text { occupation }\end{array}$ & $\begin{array}{c}\text { Husband's } \\
\text { age }\end{array}$ & $\begin{array}{c}\text { Husband's } \\
\text { education }\end{array}$ & $\begin{array}{c}\text { Husband's } \\
\text { occupation }\end{array}$ & $\begin{array}{c}\text { Family } \\
\text { size }\end{array}$ \\
\hline \hline Women's education & $-.151-*$ & & & & & & \\
Women's occupation & $-.089-$ & $-.053-$ & & & & & \\
Husband's age & $.936 * *$ & .031 & .052 & & & & \\
Husband's education & .018 & $.719 * *$ & .107 & .072 & & & \\
Husband's occupation & .075 & .058 & $.464 * *$ & .104 & $.188^{*}$ & & \\
Family size & .011 & $-.152-*$ & .028 & .068 & $-.203-*$ & .001 & .097 \\
Socio-economic level & $-.217-* *$ & $.694 * *$ & .018 & $-.055-$ & $.595 * *$ & .097 & $-.075-$ \\
\hline
\end{tabular}

*. Correlation is significant at the 0.05 level (2-tailed).

**. Correlation is significant at the 0.01 level (2-tailed). 
دراسة هقارنة حول الصناعات الصغيرة التي تقوم بهها النساء في جمعيات الأسر المنتجة في ثلاث همافظات.

حنازاخحدرضا رضا الجمل

**

سهر فوزي محمد
د ـ هويد ا مصطف زغلول

الملخص العربي

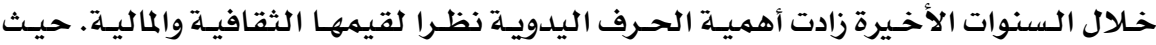

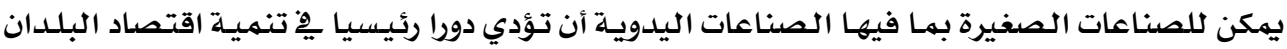

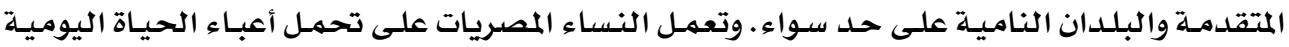

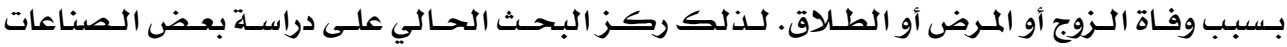

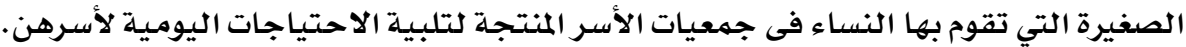

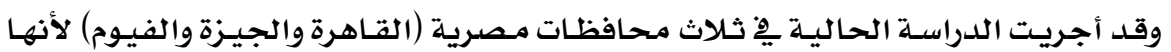

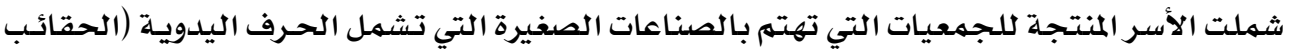

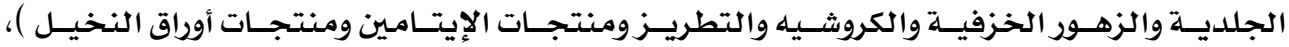

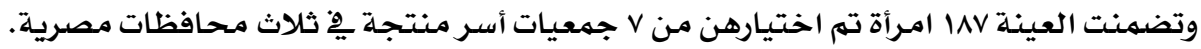

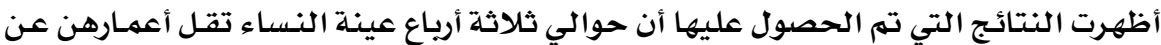

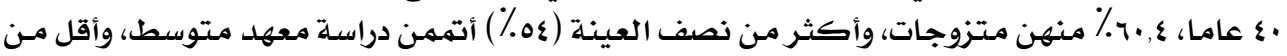

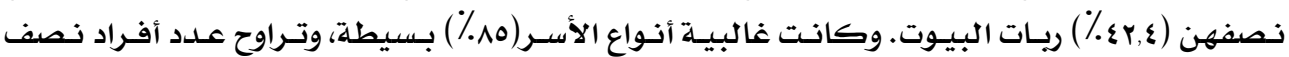

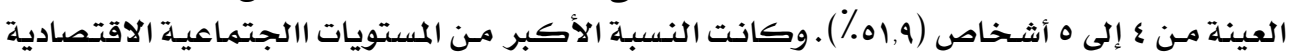

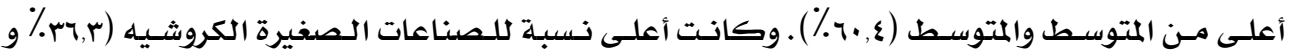

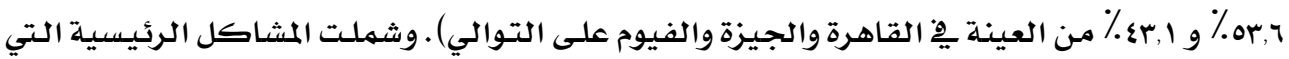

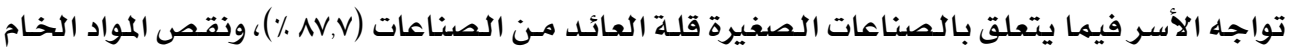

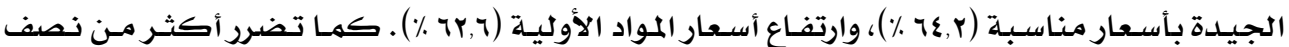

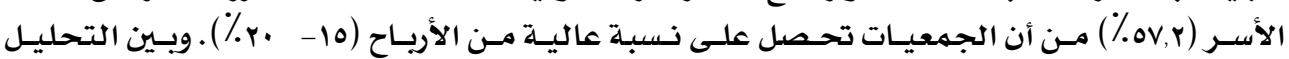

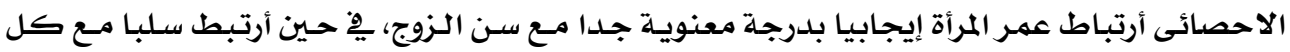

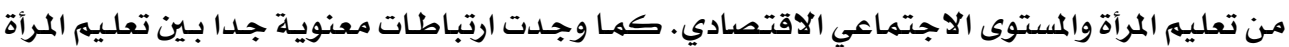

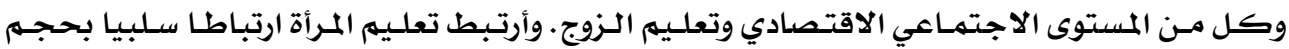

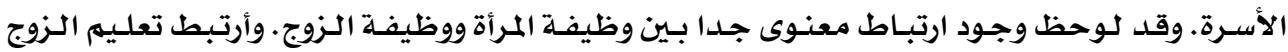

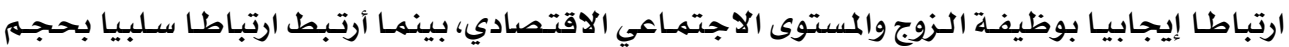

